the other two cases menorrhagia has been present as a symptom in both, and pricking the finger produced a similar result to that in the case of the man. I may further add that the microscopic examination of the blood showed a marked relative increase in the number of white corpuscles, and this doubtless has some bearing on the tendency to hæmorrhage. I venture, therefore, to agree with Dr. Shelswell in his statement that we may regard hæmorrhage as one of the symptoms of the disease.

I am, Sirs, yours faithfully,

Finsbury-square, Jan. 9th, 1888.

$$
\text { ARTHUR DAVIEs. }
$$

\section{THE RENAL GLOMERULI IN DISEASE.}

To the Editors of THE LANCET.

StRs,-In No. 19 of vol. ii. of The Lancet for 1887 on page 921,1 find, in a reference to my article, two remarks which do not entirely agree with my ideas, and which may cause me to be misunderstood. The first quotation is as follows:- "The glomerular investing membrane is, according to Hausemann, merely a layer of cells with scanty nuclei, and cannot, as usually stated, be separated into a basement membrane and endothelium." The second runs thus: " $\mathrm{He}$ finds that the delicate walls of these capillaries are simply composed of epithelium." Now, in my article, I say distinctly in several places that I make a distinction between the vessels and the investing membrane of the glomerulus (capillary tuft). The latter investing membrane, consisting only of epithelial cells, can be separated to a certain extent in its entirety, leaving behind the bare vessels, which are composed, according to Langhans, of two layers-a basement membrane and an endothelial layer. Here, in every case, I can find only a simple wall with few nuclei. In conclusion, I remark: "Die Schlingen würden in der That wahre Capillaren sein, wenn sich ihre Zellgrenzen durch Argentum nitricum darstellen liessen. So gleichen sie, wie Hortoles richtig bemerkt, den Gefässen der Hyaloidea des Frosches. I am, Sirs, yours truly,

Berlin, Dec. 23rd, 1887 DR. HAUSEMANN.

\section{NORTHERN COUNTIES NOTES. (From our own Correspondent.)}

THE HEALTH OF NEWCASTLE-ON-TYNE.

ALTHOUGH there has been a further decline in the deathrate of the city, which is so far satisfactory, a rate of 25 per 1000 is far too high, and it is to be hoped that our sanitary authorities will not relax their endeavours to reduce it still lower, and if possible keep it there. The public press has shown an intelligent activity in the matter, and the Newcastle Daily Leader has done good work by its special commissioner, who has pointed out many dark spots in the sanitary map of the city. In this gentleman's opinion the defects are due more to neglect on the part of the sanitary inspectors and to want of proper scavenging than te any fault on the part of the engineer's staff. This is all very well, and so far I agree with him, but the causes are more complex than touched upon in the report of the Leader's commissioner. Coming here a stranger, he would, as a matter of course, in a casual inspection, see merely the outsides of things, and could know little or nothing about the domestic and out-door lives of the people. Apparently he has not visited the "Iong bars," nor has he touched upon the "sweating system" so fully explained at the late meeting of the Irades' Council, where it was pointed out that the system tends to spread infectious diseases, where in some ceses one room serves for a workshop and lodging for several people in carrying on what is known by the "sweating system" of cheap tailoring. It is well known to all medical men here that the occupation of new houses before they are properly dried is a fruitful source of many diseases tending to swell the death-rate. I do not know whether our Corporation bave any bye-law relative to the inspection of these new houses, but I am quite sure that it is not properly carried out.

NEWCASTLE HOSPITAI SUNDAY FUND,

The final lists of the hospital collection have now been published, and I regret to $s \in \theta$ a considerable falling off in the amount- $£ 373,-a$ s compared with the collection of 1886 .
The change in the constitution of the Royal Infirmary will artly account for this. Many of the workshops extend their collections over the year, and remit them to the iufirmary. Newcastle-on-Tyne, Jan. 11th.

\section{ABERDEEN. \\ (From our own Correspondent.)}

THE MEDICAL OFFICER OF HEALTH.

Dr. Thomson left to-day for Sheffield, and Dr. McKenzie Booth has entered upon his duties as interim medical officer. It has not yet been decided what position Dr. Thomson's successor is to occupy. At a meeting of the Public Health Committee held on the 4 th inst, the convener, Dr. Moir, submitted two alternative proposals, which he asked the committee to consider in view of the appointment of a medical officer. The first was that the terms of appointment be as at present-that is, the gentleman appointed must devote his whole time to the duties of the office, but in future he must reside at the City Hospital; and the other proposal was that a young man should be appointed to reside at the hospital, and that " a really firstclass medical man," having a practice of his own, should be appointed medical officer, his dutios being to visit the hospital about once a day and give his services when required to the sanitary inspector, and for this he is to receive a "salary of about $f 80$ "; the young resident physician is also to have a salary of $f 80$, but in addition he is to be provided with board and lodging. It was agreed that in any case the sanitary inspector is to be, as at present, the head of the sanitary department, having the charge and direction of the other members of the sanitary staff, including the persons engaged in the cleansing and disinfecting of infected clothing, and he is to be responsible to the Town Council for the efficiency of his department. The superintendence of the disinfecting of infected clothing is au addition to the present duties of the sanitary inspector, and is the result of complaints made to the Public Health Committee with regard to children sent home convalescent from the City Hospital being the cause of a renewed outbreak of fever in their families.

THE OFFICE OF POLICE SURGEON.

By the resignation of Dr. Theodore Thomson, the office of police surgeon also becomes vacant, and at their meeting the Public Health Committee had before them a representation from the superintendent of police suggesting that some medical man other than the medical officer of health should be appointed police surgeon. The reasons given for the proposed change were that difficulty had often been experienced in regard to accident and other cases in securing the services of the medical officer when they were required, and that the members of the police force were averse to having. as their medical attendant an official who was largely occupied in the treatment of infectious diseases.

CONTRAVENTION OF THE PUBLIC HEALTH ACT.

A young man, a grocer's assistant, was charged in the police court on Wednesday the 4th inst. "with having. while suffering from an infectious disease-namely, scarlet fever-wilfully exposed himself in Rosemount-place, entered a hackney carriage, driven in the carriage to the railway station, walked among the people at the station, and entered a railway carriage, without proper precaution against spreading the disorder." The lad's parents lived in the country, and after his removal to his home some members of the family continued to attend school, and the result was an outbreak of scarlet fever in the district. He pleaded guilty, and the baillie, remarking on the grave nature of the case and the very serious results that had followed the thoughtless action of the accused, imposed a fine of a guinea, with $£ 11$ s. $3 d$. costs, the alternative being ten days' imprisonment.

$$
\text { THE CITY HOSPITAL. }
$$

On Jan. 4th there were only thirty-seven cases of zymotic disease in the City Hospital, one being a case of small-pox two or three of typhus fever, and the oth ers of scarlet fever. There were no deaths in the hospital during the month of December. The building of the new pavilion cost $£ 908$, and, by architects' fees and furnishings, exclusive of heating apparatus, the expense was brought up to $£ 1602$. At a meeting of the Public Health Committee it was remitted to 